University of Nebraska - Lincoln

DigitalCommons@University of Nebraska - Lincoln

Mammalogy Papers: University of Nebraska

State Museum

Museum, University of Nebraska State

$5-1-1967$

\title{
A New Subspecies of the Fringe-Tailed Bat, Myotis thysanodes, from the Black Hills of South Dakota and Wyoming
}

J. Knox Jones Jr.

University of Kansas

Hugh H. Genoways

University of Kansas, h.h.genoways@gmail.com

Follow this and additional works at: https://digitalcommons.unl.edu/museummammalogy

Part of the Biodiversity Commons, and the Zoology Commons

Jones, J. Knox Jr. and Genoways, Hugh H., "A New Subspecies of the Fringe-Tailed Bat, Myotis thysanodes, from the Black Hills of South Dakota and Wyoming" (1967). Mammalogy Papers: University of Nebraska State Museum. 40.

https://digitalcommons.unl.edu/museummammalogy/40

This Article is brought to you for free and open access by the Museum, University of Nebraska State at DigitalCommons@University of Nebraska - Lincoln. It has been accepted for inclusion in Mammalogy Papers: University of Nebraska State Museum by an authorized administrator of DigitalCommons@University of Nebraska Lincoln. 


\title{
A NEW SUBSPECIES OF THE FRINGE-TAILED BAT, MYOTIS THYSANODES, FROM THE BLACK HILLS OF SOUTH DAKOTA AND WYOMING
}

\section{J. Knox Jones, Jr., and Hugh H. Genoways}

\begin{abstract}
A new subspecies of Myotis thysanodes, possibly representing a disjunct population, is described from the Black Hills of South Dakota and Wyoming. The new race is compared with $M$. $t$. thysanodes and also with Myotis evotis evotis, which it superficially resembles.
\end{abstract}

On 10 August 1929, D. N. Moulthrop and G. W. Phillips of the Cleveland Museum of Natural History obtained two fringe-tailed bats, Myotis thysanodes, at Jewel Cave, South Dakota. These specimens, subsequently reported by Bole (1935: 147-148), were far to the east of the previously known range of the species, and have remained until now the only $M$. thysanodes on record from the Black Hills region. In July of 1965, a field party from the Museum of Natural History, The University of Kansas, netted a male of this species at the entrance to an abandoned mine in Weston County, Wyoming. Later in the same summer, Larry N. Brown and associates of The University of Wyoming captured a male in Custer County, South Dakota, and the following summer collected five additional specimens there. These, along with two individuals (one from South Dakota and one from Wyoming) previously reported in the literature as Myotis evotis, bring to 11 the number of fringetailed bats known from the Black Hills.

Study of 10 of these specimens, eight adults and two subadults, reveals that they represent an hitherto unrecognized subspecies, which is named and described below.

\section{Myotis thysanodes pahasapensis, new subspecies}

Holotype.-Adult male, skin and skull, no. 100,704 Museum of Natural History, The University of Kansas, from 6 miles N Newcastle, $6000 \mathrm{ft}$, Weston Co., Wyoming; obtained on 2 July 1965, by Ronald W. Turner, original no. 156 .

Geographic distribution.-Known only from the Black Hills of South Dakota and Wyoming; altitudinal range from approximately 3800 to $6150 \mathrm{ft}$.

Diagnosis.-A medium-sized (see measurements) subspecies of Myotis thysanodes characterized by a long ear, short forearm, narrow skull, shallow braincase, and attenuated rostrum.

Measurements $(\mathrm{mm})$.- External measurements of the holotype, followed by the average (and extremes) of eight adults including the holotype (six males and two females) from the Black Hills are: total length, 95, 93.4 (91-96); length of tail, 41, 41.2 (40-44); length of hindfoot, 12, 10.6 (9-12, seven specimens only); length of ear from notch, 20, 18.7 (17-21); length of forearm, 40.7, 41.1 (39.2-43.3); the holotype weighed $6.0 \mathrm{~g}$ whereas another male from Weston County, Wyoming, weighed 7.0.

Cranial measurements of the holotype, followed by the average (and extremes) of seven adults including the holotype (five males and two females), are: greatest length of skull (including incisors), 16.5, 16.7 (16.4-17.0); condylocanine length, 15.3, 15.7 (15.3$16.1)$; zygomatic breadth, $10.1,10.2$ (10.0-10.5, five specimens only); interorbital constriction, 3.8, 3.9 (3.7-4.1); breadth of braincase, 7.6, 7.7 (7.4-8.1); mastoid breadth, 8.0, 


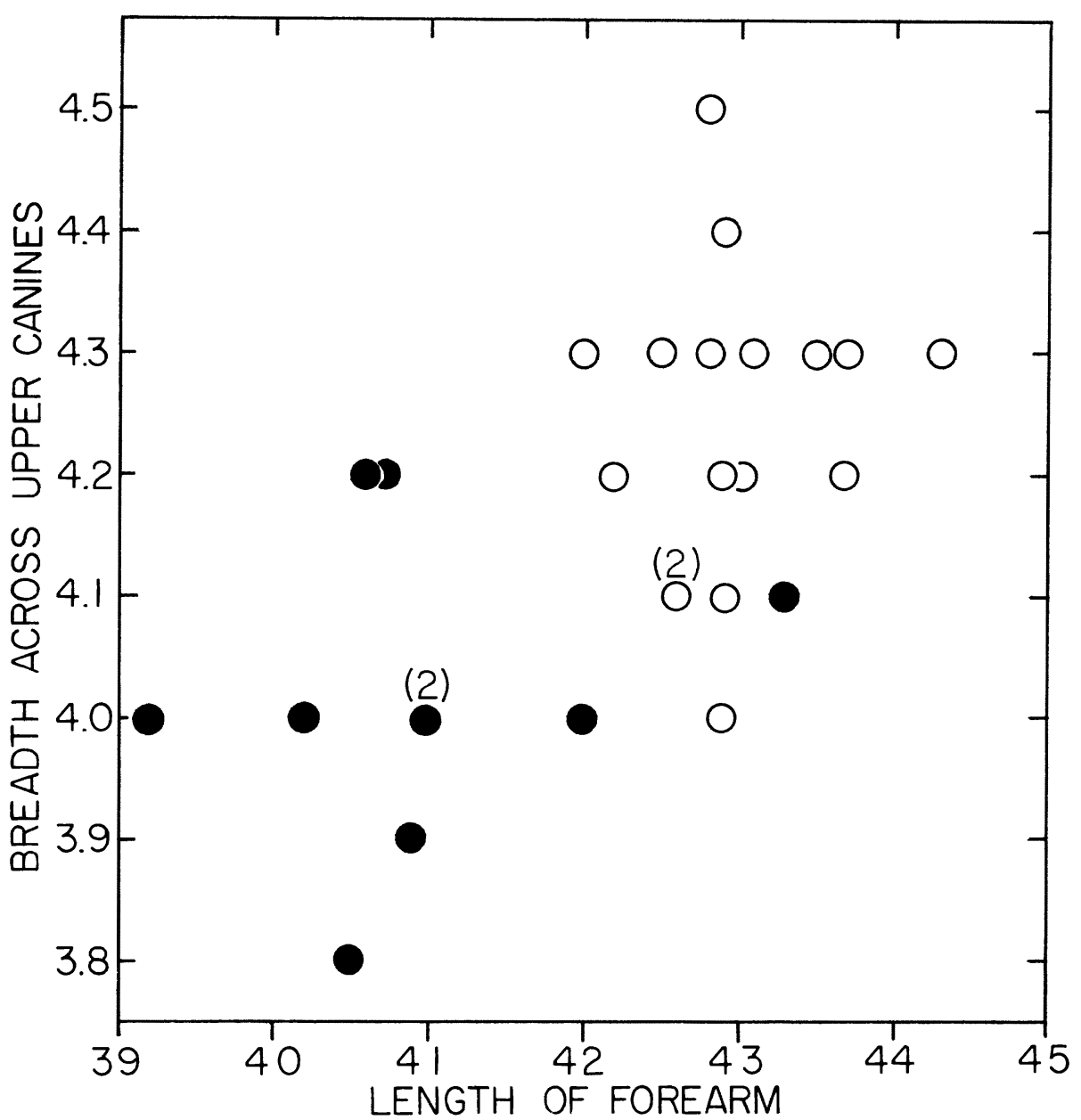

Fig. 1. Scatter diagram on which the breadth across the upper canines is plotted against length of forearm for 10 specimens of M.t. pahasapensis (solid symbols), eight adults and two subadults, and 17 adults of $M . t$. thysanodes (open symbols).

$8.3(8.0-8.6)$; length of maxillary tooth-row, $6.4,6.4(6.1-6.8)$; breadth of palate across third upper molars, 6.3, 6.6 (6.3-6.9).

Description and comparisons.- - Upper parts varying overall in adults from between Buckthorn Brown (capitalized color terms from Ridgway, 1912) and Tawny-Olive to Light Ochraceous-Buff, individual hairs blackish basally; underparts Pale OchraceousBuff to Light Ochraceous-Buff, admixed with grayish or blackish where the basal portions of individual hairs are exposed; ears and membranes blackish brown (save for one specimen in which they are brownish), contrasting noticeably with ochraceous dorsum; fringe of pale, straw-colored hairs (not especially conspicuous in some individuals) extending 1.0 to $1.5 \mathrm{~mm}$ beyond edge of median parts of posterior border of uropatagium.

From Myotis thysanodes thysanodes (see list of specimens beyond), M. t. pahasapensis differs principally as follows: ears longer, averaging 18.7 as opposed to 16.2 (15-18) in 17 specimens from Arizona and New Mexico, and forearm shorter, averaging 41.1 as 
opposed to 43.0 (42.0-44.3-also, 43.6 and 44.2 in single specimens from Colorado and Idaho, respectively); ears and membranes averaging darker, usually contrasting more with dorsal pelage; skull averaging narrower throughout (except in mastoid breadth) and slightly smaller; braincase shallower and less inflated upon direct comparison; rostrum narrower and frequently more attenuated.

The general narrowness of the cranium is best illustrated by comparison of selected measurements. Averages of our adults of pahasapensis compare with those of 20 specimens of thysanodes from Arizona and New Mexico as follows: breadth of braincase, 7.7 as opposed to 7.9 ; breadth of palate across third upper molars, 6.6 and 6.7 ; interorbital constriction, 3.9 and 4.0; zygomatic breadth, 10.2 and 10.4 ( 15 specimens only); breadth across upper canines, 4.0 and 4.2. We find little overlap between pahasapensis and thysanodes when length of forearm is plotted against various measurements of cranial breadth (Fig. 1).

Remarks.-In the most conspicuous ways in which M. t. pahasapensis differs from $M . t$. thysanodes-larger ears, shorter forearms, more contrast in color between dorsal pelage and membranes, and a smaller skull that is relatively narrow-the new subspecies superficially resembles, sometimes strikingly, Myotis evotis evotis of the western Dakotas, eastern Wyoming, and adjacent regions. Aside from Bole's (loc. cit.) original report of thysanodes from the Black Hills, the only other specimens of pahasapensis mentioned in the literature have been referred to $M$. evotis-one of three specimens listed by Stebler (1939: 389) from Custer State Park, South Dakota (the other two are $M$. keenii), and one from Weston County, Wyoming (Long, 1965: 532). As a matter of fact, the first three pahasapensis we examined were long-eared $(20,20$, and $21 \mathrm{~mm})$ and were initially thought to be evotis with exceptionally well-developed fringes on the uropatagia.

The most useful characters by means of which thysanodes can be distinguished from evotis in western South Dakota and adjacent Wyoming are external-smaller, usually shorter ears; longer forearm; and the presence of the uropatagial fringe of hairs. The ear averages 18.7 in thysanodes whereas it averages more than 20 (19-22) in evotis examined from the region; in direct comparison, the ears of thysanodes always appear smaller overall than those of evotis even when the recorded length is the same. The forearm of evotis is shorter (averaging 38.6 in 14 specimens from Harding County, South Dakota); the largest evotis examined measured 39.3 and the smallest thysanodes 39.2 (the only one of our 10 specimens in which the measurement was less than 40). The uropatagial fringe, always present and usually conspicuous in thysanodes, is inconspicuous in most evotis; we have seen a few, however, that possess a fringe comparable with the least-developed fringe among our M. t. pahasapensis.

Individuals of the two species also resemble each other cranially. Upon direct comparison, the skull of $M$. t. pahasapensis averages larger overall, has a better-developed sagittal crest, a slightly higher and more inflated braincase, somewhat more robust molar teeth, and the breadth across the third upper molars usually exceeds the length of the maxillary tooth-row (in evotis these two measurements are about the same). We know of no specimens of Myotis 


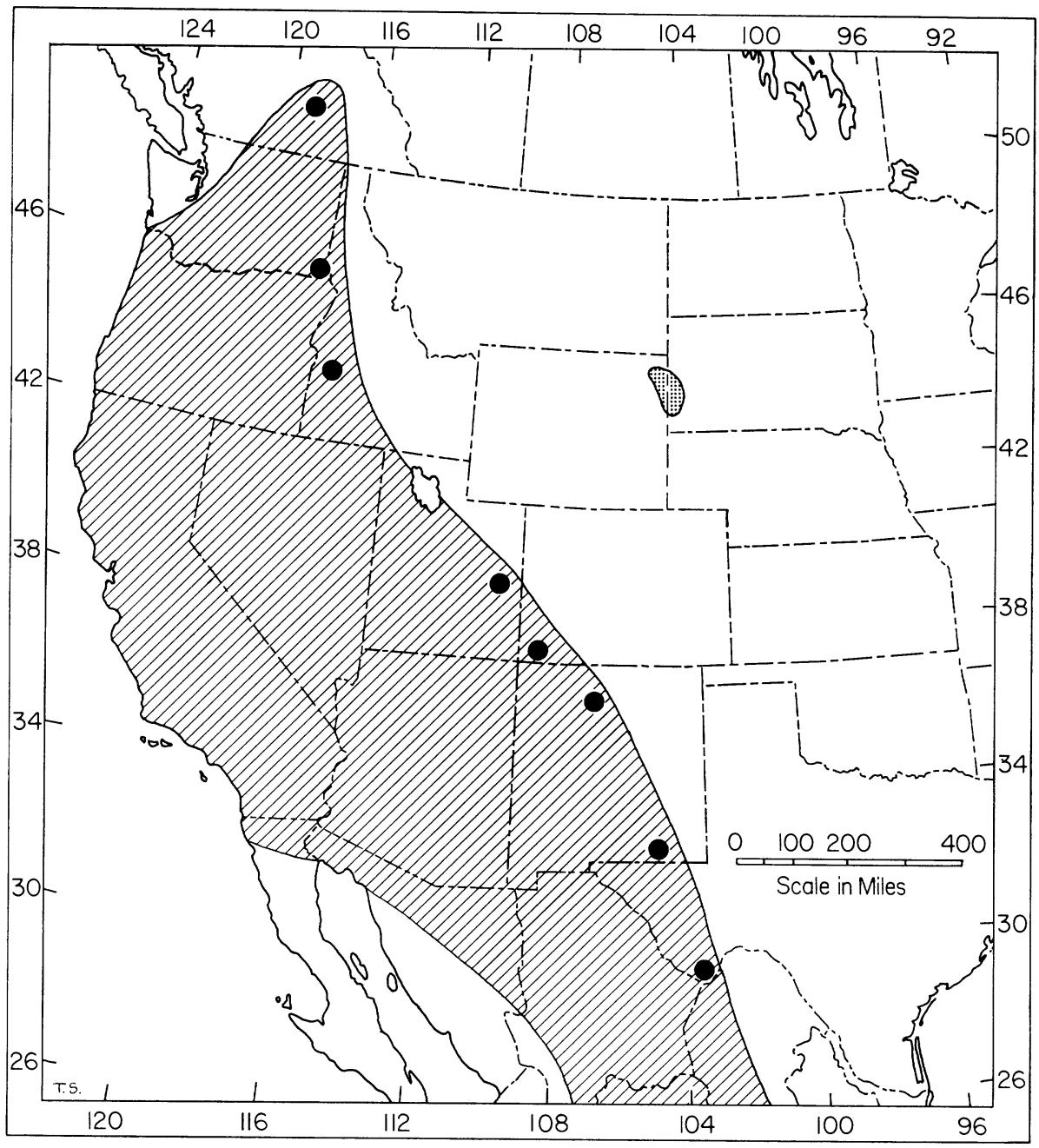

Fig. 2. Geographic distribution of Myotis thysanodes in western North America. Diagonal lines indicate the known distribution of $M . t$. thysanodes; the easternmost records of the subspecies are indicated. The stippled area in western South Dakota and northeastern Wyoming indicates the known distribution of $M$. t. pahasapensis.

evotis obtained in the Black Hills proper. Possibly evotis and thysanodes are more or less ecologically separated in the region, although existing information is yet too scanty to establish this point.

$M$. $t$. pahasapensis may represent a disjunct population, isolated on the Black Hills and separated from the range of $M$. $t$. thysanodes to the west by a distance of approximtely 500 miles (see Fig. 2). In any event, no specimens of thysanodes presently are known from Montana or from Wyoming outside the Black Hills. The single specimen reported from Colorado is from the 
southwestern part of that state and the species is known from but three localities in Utah.

We do not know the means by which the two specimens taken in 1929 at Jewel Cave were captured nor do we know the conditions under which the specimen from Custer State Park listed as evotis by Stebler (1939) was obtained. All other specimens examined from Custer County, South Dakota, were captured in mist nets-five at the entrance to Jewel Cave and one over a creek north of Hot Springs. Of the Wyoming specimens, the male from $1 \frac{1 / 2}{12}$ miles $\mathrm{E}$ of Buckhorn was shot as it foraged at dusk in company with Eptesicus fuscus pallidus and the male from 6 miles $\mathrm{N}$ of Newcastle was netted at the entrance of an abandoned coal mine along with Myotis leibii ciliolabrum.

The subspecific name pahasapensis is derived from the Sioux Indian name for the Black Hills-paha sapa.

Specimens examined.-SOUTH DAKOTA. Custer County: Custer State Park, 1 (UMMZ); Jewel Cave, 6 ( 1 UMMZ-formerly Cleveland Mus. Nat. Hist., 5 UW); 3 mi. N Hot Springs, 1 (UW). WYOMING. Weston County: 11/2 mi. E Buckhorn, 1 (KU); 6 mi. $\mathrm{N}$ Newcastle, 1 (KU).

The specimens listed below were used in comparisons reported in the foregoing text, and are in the Museum of Natural History at The University of Kansas unless otherwise noted.

Myotis thysanodes thysanodes.-ARIZONA. Cochise County: 2 mi. S Portal, 1; Reef Mine, Huachuca Mts., 2. Coconino County: Two Guns Canyon Diablo, $30 \mathrm{mi}$. E Flagstaff, 1. Gila County: Wilbanks' Ranch, Sierra Ancha, 1. CALIFORNIA. San Diego County: $1 \mathrm{mi}$. N Julian, 1; La Puerta Valley, 2. COLORADO. Montezuma County: Rock Springs, $7400 \mathrm{ft}$, Mesa Verde National Park, 1. IDAHO. Boise County: Karney Lake, 1. NEW MEXICO. Catron County: 4 mi. E, 2 mi. N Alma, 2. Eddy County: Carlsbad Cavern, 2; McKittrick Cave, 20 mi. SW Carlsbad, 29; Vandalize Cave, Carlsbad Caverns National Park, $4500 \mathrm{ft}$, 3. Socorro County: Ruins of Gran Quivera, Mesa Jumanes, 1.

Myotis evotis evotis.-MONTANA. Fergus County: Big Snowy Mts., $18 \mathrm{mi} . \mathrm{S}, 3 \mathrm{mi}$. W Lewistown, $6600 \mathrm{ft}, 1$. Powder River County: Powderville, $2900 \mathrm{ft}, 1$. NORTH DAKOTA. Billings County: $1 \mathrm{mi} . \mathrm{S}, 1 \mathrm{mi}$. W Medora, $2300 \mathrm{ft}, 1$. SOUTH DAKOTA. Harding County: $7 \mathrm{mi} . \mathrm{S}, 4 \frac{1}{2} \mathrm{mi}$. E Harding, 1; $10 \mathrm{mi}$. S, $5 \mathrm{mi}$. W Reva, 13. WYOMING. Albany County: Wyoming Game and Fish Experimental Unit, 1 (UW). Carbon County: Bottle Creek Picnic Ground, Sierra Madre Mts., $8700 \mathrm{ft}, 2$. Converse County: Carenther's Cave, 17 mi. SW Douglas, 1 (UW). Park County: $15 \mathrm{mi}$. S, $21 \mathrm{mi}$. W Cody, $6200 \mathrm{ft}, 1$. Sublette County: $3 \mathrm{mi}$. E, $6 \mathrm{mi}$. N Pinedale, $7500 \mathrm{ft}, 1$.

Acknowledgments.-For the loan of specimens we are grateful to Dr. W. H. Burt, University of Michigan Museum of Zoology (UMMZ) and to Dr. L. N. Brown, Department of Zoology, University of Wyoming (UW).

\section{Literature Cited}

Bole, B. P., Jr. 1935. Myotis thysanodes in South Dakota. J. Mamm., 16: 147-148.

LonG, C. A. 1965. The mammals of Wyoming. Univ. Kansas Publ., Mus. Nat. Hist., 14: 493-758.

Ridgway, R. 1912. Color standards and color nomenclature. Privately published, Washington, D. C., iii +43 pp.

Stebler, A. M. 1939. An ecological study of the mammals of the Badlands and the Black Hills of South Dakota and Wyoming. Ecology, 20: 382-393.

Museum of Natural History, The University of Kansas, Lawrence. Accepted 5 January 1967. 